"Delegates of the head of the Nation": the Provincial President's Function in the Formation of the Brazilian Empire (1823-1834)

\title{
"Delegados do chefe da nação": a função dos presidentes de província na formação do Império do Brasil (1823-1834) $^{1}$
}

\section{Andréa Slemian}

Doutora em História pela

Universidade de São Paulo
Uma versão preliminar do texto foi apresentada no Seminário Internacional Brasil: de um império a outro (1750-1850), realizado no Departamento de História/USP, em setembro/2005. A autora agradece as valiosas sugestões que, na ocasião, foram feitas por Miriam Dolhnikoff e João Paulo G. Pimenta.

\section{Resumo}

0 artigo analisa a criação normativa da função de presidente de provincia no Brasil pós-Independência como uma das facetas do conflituoso processo de construção de novas bases constitucionais para o projeto de Império. Defende-se aqui que a instituição dos mesmos presidentes vinculou-se diretamente à necessidade de separação e equacionamento entre os novos poderes políticos (executivo e legislativo) que, tão cara à época, foi um dos desafios para nossos primeiros legisladores.

\section{Abstract}

The article analyzes, in the post-Independence period, the legal creation of the Provincial President's function as one of the sides of the conflicting process of developing new constitutional basis for the Empire. It points out that the political role of such presidents was directly linked to the need for separation and balance between the new political powers (executive and legislative) which, so significantly in those days, was one of the challenges for our first legislators.

\section{Palavras-chave}

constituição, debates parlamentares, representações políticas, poder legislativo, império, Primeiro Reinado

\section{Keywords}

constitution, parliamentary debates, political representations, legislative power, empire, First Reign 
Órgãos criados pela Carta Constitucional de 1824, mas implementados nas províncias apenas após a aprovação de uma lei para sua regulamentação em 1828.

3

Annaes do Parlamento Brasileiro. Câmara dos Deputados. Sessão de 1830 (APB-CD 1830). Rio de Janeiro: Typographia de Hypollito José Pinto e \& Cia, t. I, 1878, sessão de 26/maio. p.238.

4

FIORAVANTI, Maurizio. Constitucion. De la Antiguedad a nuestros dias. Madri: Ed. Trotta, 2001.

5

SLEMIAN, Andréa. Sob o império das leis: Constituição e unidade nacional na formação do Brasil (1822-1834). 2006. Tese (Doutorado em História Social). Faculdade de Filosofia, Letras e Ciências Humanas, Universidade de São Paulo, São Paulo, 2006.

DOLHNIKOFF, Miriam. Construindo o Brasil: unidade nacional e pacto federativo nos projetos das elites (1820-1842). 2000. Tese (Doutorado em História Social). Faculdade de Filosofia, Letras e Ciências Humanas, Universidade de São Paulo, São Paulo, 2000. p.62-3; BARMAN, Roderick. Brazil. The forging of a nation 1798-1852. Stanford: Stanford University Press, 1988. cap. 4.
Em sessão de maio de 1830, quando os membros da Câmara dos Deputados do Brasil mais uma vez discutiam as atribuições dos Conselhos Gerais de Província2, o deputado baiano Lino Coutinho foi enfático sobre a necessidade dos presidentes thes prestarem esclarecimentos de suas deliberações. Dizia-se convencido de que na Casa predominaria opinião contrária, e que "se quer[ia] fazer dos presidentes outros tantos capitães-generais" com ausência de limites aos seus poderes, como afirmava ter sido a regra para seus congêneres durante a colônia. Proclamava a tarefa que caberia a eles, como legisladores:

se nós não fizermos dos presidentes das províncias homens constitucionais, que só obrem na conformidade da lei, nada temos feito, porque o despotismo, como disse o Sr. [Diogo Antônio] Feijó, depende mais desses bachás que governam as provincias. ${ }^{3}$

Aparentemente banal, a afirmação de Coutinho trazia à tona uma polêmica, cara à sociedade da época, acerca da necessidade de construção de uma estrutura político-institucional que, após a consumação da Independência, deveria necessariamente repousar sobre moldes constitucionais. 0 que significava dizer que, por mais conservador que pudesse ser o processo político em curso, a opção por um regime de governo que pretendia se contrapor ao absolutismo implicava a busca de soluções para duas questões centrais aos Estados após o advento das revoluções liberais em todo o mundo atlântico: a de uma equação balanceada de separação e controle entre os poderes políticos (legislativo, executivo, judiciário e, no caso brasileiro, moderador), e a da gestação de novas formas de representação política que pudessem atender à premissa de garantia dos direitos inalienáveis dos cidadãos. ${ }^{4}$

Nestes termos, o clamor do baiano era para que as atribuições dos presidentes de provincia fossem regulamentadas, o que desde a criação do cargo em 1823, e sua confirmação no texto constitucional do ano seguinte, não fora ainda objeto de lei específica. Sua reivindicação esteve longe de destoar do contexto em que foi proferida, já que o andamento dos trabaIhos da Câmara, desde sua abertura em 1826, era marcado por um evidente esforço para criação, normalização e eficácia das instituições públicas. ${ }^{5}$ Nesse sentido, associava-se positivação das leis à garantia de estabilidade interna, ao mesmo tempo em que se valorizava o papel dos legisladores enquanto artífices de uma estrutura política que se construía como simulacro da ordem.

Obviamente que essa tarefa foi marcada por conflitos, sendo mais que sabido que a Independência não consagrou, de imediato, uma nova unidade política e os anos que a ela se seguiram foram de intensa disputa entre projetos políticos distintos no tocante ao futuro das partes que até então compunham a América portuguesa. Ainda que o anseio por um arranjo constitucional que contemplasse os interesses locais tenha feito com que muitas províncias se dispusessem a eleger seus deputados para a Assembléia Legislativa e Constituinte instalada em 1823 e efetuassem seu apoio à "causa do Brasil"6, sua abertura trouxe à tona o nível de disputa então existente na Corte. No âmbito do debate parlamentar, a roupagem consensual em torno da monarquia constitucional, muitas vezes referida como compativel com alternativas federativas de governo, não escondia uma diversidade de concepções sobre a arquitetura dos poderes e o peso das instituições a serem criadas. Diversidade esta alimentada no início dos anos trinta com a Abdicação e a possibilidade de concretização de uma reforma da Carta de 1824. 
Em meio a esse cenário, os embates pela criação normativa do cargo dos presidentes como responsáveis pelo executivo nas províncias são reveladores das tensões existentes entre os deputados. Houve falta de consenso desde as primeiras discussões sobre a questão, tornando-se evidente que o equilibrio entre os poderes, tanto no interior das províncias como destas para com o governo que se pretendia central, era o ponto principal de discórdia entre as várias posições. Nosso objetivo aqui é mapear essa polêmica na Câmara de representantes desde o momento em que ela surgiu, quando da criação da lei dos governos provisórios para as províncias em 1823, até a discussão da reforma constitucional, em 1834, passando pelas tentativas de se estabelecer um regimento para os mesmos presidentes e Conselhos Gerais durante o Primeiro Reinado.

Deve-se destacar que, mesmo em meio aos conflitos, definições cruciais em relação à função dos presidentes foram aprovadas nesse período, as quais mostrariam ter vida longa Império adentro. Sustenta-se que, no âmbito da discussão do ordenamento jurídico, a tentativa de proposição e controle da ação presidencial esteve diretamente ligada à implementação de uma instância de "representação dos povos" como seu contraponto. Foi assim que a aprovação das Assembléias Provinciais, com o Ato Adicional em 1834, sob o clamor de uma maior autonomia legislativa em relação à Corte, abriria terreno para que finalmente se aprovasse um regimento para os presidentes no mesmo ano. Este regimento significou, a partir de um programa de reforma da Constituição que primava pela moderação política, não só a consolidação, mas o reforço do papel do presidente como uma das principais autoridades nas províncias. Trocando em miúdos: aumentar o poder da instância representativa popular significou dar maiores atribuições ao representante do executivo local, o que, na concepção normativa predominante, é um dos exemplos mais evidentes da busca pelo equilibrio entre os poderes na nova perspectiva constitucional moderna.

Pelas razões apontadas, a análise das discussões travadas entre os deputados ganha dupla relevância. Por um lado, porque os embates no ambiente parlamentar enunciam divergências entre distintos projetos e interesses de grupos representados na Assembléia; por outro, pelo fato das formulações não se reduzirem a um simples reflexo dessas posições, mas se vincularem a um complexo universo discursivo que exigiu extrema capacidade dos coevos em conceberem um ordenamento da realidade social para construção de uma nova unidade política. Projetava-se para o futuro a tarefa de sua consolidação.

\section{A Assembléia Constituinte de 1823 e a criação do cargo dos presidentes de província}

Do ponto de vista da organização institucional do Império do Brasil, observa-se já na década de vinte uma notável valorização da esfera provincial de poder em detrimento do âmbito municipal, que perderia substancialmente sua autonomia predominante durante toda a colônia. Apesar de D. Pedro I ter se dirigido às Câmaras para solicitar a apreciação da Carta Constitucional de 1824, demonstrando reconhecê-las como locus legítimo de

7

LOPES, José Reinaldo de Lima. Iluminismo e jusnaturalismo no ideário dos juristas da primeira metade do século XIX. In: JANCSO, István (org.). Brasil: formação do Estado e da Nação. São Paulo/ljui: Fapesp/Hucitec/Unijuí, 2003. p.195-218 representação política (em oposição à Assembléia que ele tinha fechado) ${ }^{7}$, os trabalhos legislativos que se iniciaram no ano anterior demonstraram o consenso quanto a se investir numa outra direção. Tal posição vinha na esteira das transformações produzidas após a eclosão do movimento constitucional no mundo português em 1820, quando as antigas capitanias 
Diário das Cortes Gerais e Extraordinárias da Nação Portuguesa, disponiveis na internet: www. debates.parlamento.pt Sessão de 29 de setembro de 1821. Decreto sobre as Juntas Provisórias do Governo.

9

No mesmo dia fora aprovado um outro decreto que exigia que o Principe Real regressasse para Portugal.

10

Nesse sentido, ver a análise da experiência da Junta de Governo em Pernambuco analisada por BERNARDES, Denis Antônio de Mendonça. 0 patriotismo constitucional: Pernambuco, 18201822. São Paulo/Recife: Hucitec/Fapesp, 2006. cap.7.

11

BERBEL, Márcia Regina. A nação como artefato. Deputados do Brasil nas Cortes portuguesas 1821-1822. São Paulo: Hucitec/Fapesp, 1999. cap. 4.

\section{2}

A Assembléia abriu seus trabalhos em 03 de maio, e logo na sessão do dia 07 foi apresentado o projeto para regulamentação de um governo para as províncias de José de Sousa Mello, deputado por Alagoas, seguido dois dias depois pelos de Antônio Carlos Ribeiro de Andrada, eleito por São Paulo, e de Antonio Gonçalves Gomide, de Minas Gerais. Diário da Assembléia Geral Constituinte e Legislativa do Império do Brasil 1823 (edição fac-simile). Brasilia: Senado Federal, 1973, v. 1, p. $40-5$. do ultramar - que até então existiam predominantemente como espaços administrativos - ganharam uma dimensão política crescente e receberam a nomeação definitiva de províncias.

Nesse sentido, as Cortes Constituintes instaladas em Lisboa em 1821 aprovaram um decreto para criação das Juntas Provisórias ${ }^{8}$ como tentativa de organização do Reino do Brasil sob um novo regime. A medida, que tinha como objetivo regulamentar o governo das províncias e, sobretudo, controlar a atuação independente do regente D. Pedro que se encontrava no Rio de Janeiro ${ }^{9}$, deve ser considerada como uma verdadeira ruptura com a prática vigente. Em substituição aos antigos capitães generais, mandavase criar um governo composto de cinco ou sete membros, todos elegiveis na própria localidade, sujeito à autoridade central das Cortes. 0 mesmo documento atribuía, no artigo 6, à competência local "toda a autoridade e jurisdição na parte civil, econômica, administrativa, e de polícia em conformidade das leis existentes, as quais ser[iam] religiosamente observadas, e de nenhum modo poder[iam] ser revogadas, alteradas, suspensas, ou dispensadas pelas Juntas de Governo". Os magistrados e autoridades civis ficariam subordinados às mesmas Juntas, mas os Governadores de Armas - nova autoridade militar criada - seriam sujeitos à Assembléia dos representantes em Portugal.

É fato que durante os anos de 1821 e 1822, Juntas de Governo foram instaladas nas províncias do Brasil como sinal de adesão às Cortes lisboetas em meio ao clima de intensa instabilidade que reinava em muitas de suas capitais. E não há dúvida que sua prática significou um marco nas formas reinantes de se fazer política, tanto devido ao caráter eletivo de escolha de seus membros como pela possibilidade de representação dos interesses locais por via constitucional. ${ }^{10}$ Mas ainda que sua proposta de vincular o governo das províncias diretamente a Lisboa tenha sido primeiramente aprovada pelos deputados do Brasil que se encontravam na Casa legislativa, ela logo entraria em choque com o discurso de defesa da condição de Reino do Brasil - que implicava a permanência da autoridade de D. Pedro no Rio de Janeiro - encampado por grande parte dos representantes americanos a partir de $1822 .{ }^{11}$ A questão foi central na construção da alternativa da Independência concebida por grupos do Centro-Sul em função de seus interesses na manutenção da Corte carioca; alternativa esta logo apoiada por outras provincias à medida que se relevava realmente inviável a permanência da unidade portuguesa.

Com a declaração de separação de Portugal, em clima de ruptura total com a política das Cortes lisboetas, a existência das Juntas de Governo foi colocada em xeque ao mesmo tempo em que uma regulamentação das provincias aparecia como necessidade urgente. Ambas questões aflorariam com toda força na Assembléia Constituinte e Legislativa do Brasil que, instalada em maio de 1823 de acordo com a promessa feita pelo jovem Imperador - e mesmo sem a adesão de todas as partes que se pretendiam ao novo Império -, buscava fornecer as bases de legitimidade de um novo pacto político.

Na nova Casa legislativa, três propostas de lei para o governo provincial logo vieram à tona, as quais, apesar de diferentes, previam a extinção das Juntas e concordavam na escolha pelo Imperador de um presidente para cada localidade. ${ }^{12}$ Para além disso, o projeto do deputado paulista Antônio Carlos Ribeiro de Andrada, escolhido como base para a discussão, previa que o responsável pelas forças armadas na província seria independente da 
13

Diário da Assembléia Geral Constituinte e Legislativa do Império do Brasil 1823 (edição facsímile). Brasilia: Senado Federal, 1973, v.1, 16 de junho, p. 218.

\section{4}

Ibidem, p. 350

15

lbidem, 04 de julho, p. 349.

16

Ibidem, 17 de junho, p. 229 autoridade presidencial (com exceção das ordenanças e para execução dos recrutamentos), permanecendo sob ordens diretas do monarca. Também concebia um conselho eletivo não permanente que se reuniria pelos menos duas vezes por ano para auxiliar o presidente, podendo ser por este convocado quando assim the aprouvesse ou se discutissem matérias da alçada de ambos. E apesar de conceber a administração da justiça como independente do presidente e seus conselheiros, estes poderiam, apenas conjuntamente, suspender os magistrados. Em linhas gerais, tratava-se de uma proposta que previa uma centralização de poderes aos presidentes e um papel de destaque para a Corte no controle dos distúrbios regionais.

Em junho de 1823, iniciou-se a discussão do projeto - concluída apenas em 11 de outubro, após três etapas de debate - mesmo sem a presença de representantes de todas as províncias pretendidas pelo Império do Brasil. A questão da extinção das Juntas Provisórias, matéria do primeiro artigo, inaugurou a polêmica. Aqueles contrários à medida alegavam, nos moldes do paraibano Augusto Xavier de Carvalho, que elas eram "uma instituição que os povos esperaram, que receberam com gosto, e que tanto tem respeitado", e que não deveriam ser substituídas "por um só indivíduo" na figura de um presidente. ${ }^{13} 0$ padre José Martiniano de Alencar, eleito pelo Ceará, atacou a proposta de Antônio Carlos sob a acusação de se querer centralizar as decisões no Rio de Janeiro, afirmando que o fechamento das Juntas poderia ser considerado um ato "despótico" e assim causar desordens nas províncias do Norte. Apesar de outros representantes falarem contra a medida, inclusive nas duas subseqüentes discussões regulamentares da matéria, venceu a extinção da instituição eletiva.

Quando se tratou do segundo artigo do projeto, que estabelecia ser o governo provisoriamente conferido a um presidente e a um conselho, as discordâncias vieram novamente à tona. Em resposta aos críticos da matéria à semelhança da polêmica anterior, Antônio Carlos atacou as Juntas que, nas suas palavras, "formadas por eleição popular, cuidaram que ti[veram] em si o poder da nação, supuseram-se uns pequenos soberanos, e julgaram que tudo thes era permitido, e d'aqui procederam as desordens e os erros que têm feito os povos desgraçados"14. A acusação era veemente e angariou adeptos, sendo o artigo novamente aprovado. Entre os pronunciamentos então proferidos, os deputados paulistas Arouche Rendon e Nicolau Pereira de Campos Vergueiro defenderam ao menos que se criasse um regimento para o presidente e Conselho, como forma de seu controle, mas não foram momentaneamente apoiados. ${ }^{15}$

Também existiram vozes dissidentes a que o presidente, como executor e administrador da província, fosse escolhido pelo Imperador, como propunha o terceiro artigo do projeto. 0 padre Luís Inácio de Andrade Lima, eleito por Pernambuco, fez um enfático protesto contra a matéria:

Eu olho, Sr. Presidente, tão somente a utilidade dos Povos, é esta a mira da minha Política. Os Povos deste vasto Império há longo tempo, calcados pelo despotismo dos delegados dos Monarcas, olham com horror para tudo quanto seja fabricado ao segredo dos Gabinetes. Eles vêm nesse Projeto uma organização de Governo, que se diz de forma Constitucional em epílogo; mas cujas Autoridades, que mais podem, são da nomeação do Imperador; e um Conselho de nomeação popular, mas que nada mais pode senão dar conselhos, e fantasiar melhoramentos. ${ }^{16}$

É evidente que Andrade Lima ao atacar o artigo valia-se da experiência da Junta que, sobretudo em Pernambuco, havia servido de radical 
BERNARDES, Denis Antônio de Mendonça. 0 patriotismo constitucional: Pernambuco, 18201822. São Paulo/Recife: Hucitec/Fapesp, 2006.

18

Diário da Assembléia Geral Constituinte e Legislativa do Império do Brasil 1823 (edição facsimile). Brasilia: Senado Federal, 1973, v.1, 17 de junho, p. 233.

19

Ibidem, p.358.

20

lbidem, 07 de julho, p. 362.

21

Ibidem.

22

Diário da Assembléia Geral Constituinte e Legislativa do Império do Brasil 1823 (edição facsímile). Brasilia: Senado Federal, 1973, v.2, 10 de julho, p. 383-5. ruptura ao novo governo representativo após a queda de Luis do Rego Barreto em 1821.17

Ao proposto por Antônio Carlos de Andrada Machado, houve quem defendesse emenda para que cada província mandasse uma lista para o Imperador escolher o presidente; ou mesmo retirasse o direito do Imperador de demiti-lo. 0 padre Venâncio Henriques de Resende, deputado por Pernambuco, fez uma emenda conciliatória: que os presidentes fossem homens das suas respectivas províncias, ainda que escolhidos pelo monarca. Explicava que seu cargo representaria

um lugar de feitorização; é um lugar que o Imperador devia encher pessoalmente; como porém isso não é praticável nomeia seus agentes para em seu nome governarem as Províncias. Já se disse que o movimento do Poder Executivo deve ser rápido e vigoroso; se o Imperador não pudesse ad nutum remover um homem, que não é senão seu Feitor, quando visse que era mal servido, o andamento do Poder Executivo ficaria paralisado. ${ }^{18}$

0 pernambucano apoiava o artigo, em nome da separação dos poderes, ainda que tentasse garantir que o poder executivo provincial fosse atribuído a homens nascidos em cada localidade.

Por outras razões, outros deputados favoráveis à escolha do Imperador alegavam que todas as autoridades subalternas deveriam ser por ele nomeadas, e que o "meio de nomeação dos mesmos povos" nem "sempre [seria] eficaz para se obter o melhor governo"19, conforme as palavras de Manuel José de Sousa França, deputado pelo Rio de Janeiro. Da posição destes, clara era a concepção política conservadora da necessidade de controle da representação popular direta. A proposta para o Imperador escolher o presidente acabaria por vencer, ainda que se marcasse sua responsabilidade na administração de acordo com uma emenda aprovada. A despeito disso, a polêmica enunciava estar em jogo em que medida as províncias, ou os "povos", deveriam participar na escolha de suas autoridades e, assim, do governo.

Essa mesma questão continuaria a informar a discussão dos artigos seguintes. Nesse sentido, a presença e periodicidade do conselho, como órgão eletivo, nos despachos do presidente (artigos 6 e 9) também foi um ponto de atrito por tocar nos limites de ação da mesma autoridade executiva. Cândido José de Araújo Viana, de Minas Gerais, propôs emenda para que o presidente decidisse sozinho apenas nos negócios de pura execução. ${ }^{20}$ Porém, José Bonifácio de Andrada e Silva - então ministro e deputado por São Paulo, além de irmão do autor do projeto -, sustentou a matéria do jeito que estava, ou seja, para que o presidente despachasse por si mesmo sem exigir a presença do conselho. Sua justificativa era que o mesmo não seria um "capitão general", mas "muito menos do que isso; um homem que ha[veria] de executar as ordens que receber, e as leis; e que só delibera[ria] em casos extraordinários e repentinos"21. Após sua fala, uma clara defesa do poder de ação dos presidentes, nenhum outro deputado se colocou contra a medida, e novamente venceu o artigo como fora redigido.

Sobre a periodicidade do órgão, o mesmo Andrada Machado defendeu em seguida que o conselho eletivo não fosse permanente, polemizando com Henriques de Resende que assim o queria em nome de uma representação popular constante ao lado do presidente. ${ }^{22}$ Venceu a posição do padre pernambucano, com a proposição de que, não estando o conselho reunido, o presidente decidiria sobre a matéria e a comunicaria aos conselheiros o mais rápido possivel, numa tentativa de evitar os excessos que poderia 
Diário da Assembléia Geral Constituinte e Legislativa do Império do Brasil 1823 (edição facsimile). Brasilia: Senado Federal, 1973, v.2, 16 de julho, p.414.

\section{4}

OLIVEIRA, Cecilia Helena de Salles. A astúcia liberal. Relações de mercado e projetos políticos no Rio de Janeiro (1820-1824). Bragança Paulista: Edusf/Ícone, 1999. passim.

\section{5}

As discussões sobre a matéria se dariam entre os dias 17 e 23 de julho.

\section{6}

Diário da Assembléia Geral Constituinte e Legislativa do Império do Brasil 1823 (edição facsímile). Brasilia: Senado Federal, 1973, v.2, 28 de julho, p. 467-9.

27

Diário da Assembléia Geral Constituinte e Legislativa do Império do Brasil 1823 (edição facsímile). Brasilia: Senado Federal, 1973, v.3, 11 de outubro, p.226.

28

A discussão do Projeto de Constituição iniciou-se em sessão de 17 de setembro. Diário da Assembléia Geral Constituinte e Legislativa do Império do Brasil 1823 (edição fac-símile). Brasilia: Senado Federal, 1973, v.3. cometer. ${ }^{23} 0$ que comprova que, apesar da série de vitórias que alcançavam os artigos do projeto do paulista, como expressão normativa de grupos estabelecidos no Centro-Sul responsáveis pela viabilização da Independência 24 , modificações foram nele introduzidas.

Dessas mudanças, uma das mais significativas relacionava-se ao artigo 16, que estipulava originalmente ser o comandante militar independente do presidente da província e vinculado diretamente ao Rio de Janeiro. Foram predominantemente os egressos do Norte (Nordeste) que ofereceram pronto repúdio à matéria, entendendo que a independência local das forças armadas seria uma possibilidade real de intervenção indevida do governo imperial. Se no tocante ao resto do projeto e na ação legislativa em geral realizada pela Assembléia, é equivocado falar em bancadas regionais coesas quanto às discussões em curso, nesse ponto seus representantes rapidamente se alinharam. 0 que pode ser explicado pela recente experiência do envio de tropas para a região promovida pelas Cortes de Lisboa sob a justificativa de sua pacificação. A medida não foi aprovada, e a oposição a ela foi reforçada com a entrada de novos deputados, sobretudo dos baianos após o fim da guerra na província, em julho de $1823.25 \mathrm{Em}$ seguida, aprovou-se também uma diminuição no poder de ação do presidente tal qual proposto por Andrada Machado, pela decisão de que a administração da justiça Ihes seria totalmente independente, e que o "delegado do Imperador" só poderia suspender os magistrados se reunido em conselho e em caso de revolta ou motim. 26

Mais uma prova de como as tensões estiveram presentes nos meses finais dos trabalhos da Assembléia também pode ser percebida nos embates sobre os governos das províncias. Em outubro de 1823, quando já estava para terminar a última discussão sobre o projeto, o baiano Antônio Ferreira França falou contra a escolha dos presidentes pelo Imperador sob a justificativa dele não estar presente quando se aprovou a medida. Assim, mesmo sem a matéria estar em pauta, argumentou:

\section{Nós clamamos um Imperador para nos reger, e com os seus competentes direitos; mas os Povos não declararam de maneira alguma, que aqueles direitos que eles pudessem conservar se thes tirassem; eles estavam na posse de eleger os seus Governos Provinciais [...] e parece haver injustiça em se Ihe tirar a eleição destes Governos. $^{27}$}

Com isso, Ferreira França foi imediatamente chamado "à ordem". No entanto, continuou. Defendeu que ao menos os "povos" pudessem indicar ao governo os nomes dentre os quais sairia o escolhido pelo monarca, mas sua crítica foi esvaziada em nome da matéria já ter sido aprovada anteriormente.

A essa altura, a disputa entre os deputados na Assembléia era também marcada pelas controvérsias em torno de uma maior autonomia para as províncias (debate do artigo 2, título Do território do Império do Brasil, do Projeto de Constituição) ${ }^{28}$, defendida não somente por deputados do Norte, contra um arranjo centralizador da monarquia no tocante às atribuições do executivo. Do que se pode aventar que, se proposto naquele momento, o projeto do paulista Andrada Machado seria aprovado, no mínimo, com muito mais dificuldade.

Quando da dissolução da Assembléia em novembro, o projeto que dava forma, ainda que provisória, aos governos provinciais já havia se transformado em lei. Datada de 20 de outubro de 1823, nela extinguiam-se definitivamente as Juntas de Governo e estabelecia-se como autoridade 0 
29

Formado por João Severino Maciel da Costa, Luiz José de Carvalho e Mello, Clemente Ferreira França. Marianno José Pereira da Fonseca, João Gomes da Silveira Mendonça, Francisco Villela Barboza, Barão de Santo Amaro, Antonio Luiz Pereira da Cunha, Manoel Jacinto da Gama, José Joaquim Carneiro de Campos.
30

Annaes do Parlamento Brasileiro. Câmara dos Deputados. Sessão de 1826. Rio de Janeiro: Typographia do Imperial Instituto Artístico, 1874 (APB-CD 1826), t. 1, 11 de maio, p.41. presidente e um secretário, ambos escolhidos pelo Imperador, além de um Conselho privativo eletivo. Embora o presidente pudesse despachar por si só, ele deveria comunicar suas decisões aos mesmos conselheiros, os quais tinham que ser necessariamente consultados no caso da suspensão de magistrados e do comandante militar. Este último era dependente da autoridade civil nas províncias e, no caso do uso de forças "contra os inimigos internos", dependiam da aprovação da autoridade presidencial em conselho, diminuindo a ingerência direta do Rio de Janeiro. No caso da justiça, o magistrado era independente e o presidente, apenas reunido com os conseIheiros e de acordo com o chanceler (onde houvesse Relação), poderia suspendê-lo em casos de motins e revoltas. No geral, as atribuições dos "delegados do Imperador", em número de dezesseis, tratavam do fomento da agricultura, educação, estabelecimento de câmaras, proposição de obras, censos, fiscalização das contas e receitas das comarcas, decisão sobre os conflitos de jurisdição nos distritos, vigia sobre a infração das leis, cuidados com os escravos, determinação de receitas extraordinárias, sendo também responsáveis pelas Juntas da Fazenda Pública. Dessa forma, a lei dotava os mesmos presidentes de amplos poderes, ainda que estabelecesse limites para sua atuação mediante a instituição do Conselho.

A Carta Constitucional de 1824, redigida por uma comissão 29 e outorgada por D. Pedro, corroboraria as medidas da citada lei, mas introduzia uma novidade no esquema geral de funcionamento do governo das provincias. Previa que, além do presidente nomeado pelo Imperador, haveria um outro conselho - intitulado Conselho Geral de Província - em cada uma das capitais, com membros também eleitos localmente. Seu diferencial estava tanto no funcionamento independente da autoridade presidencial (já que 0 criado pela lei de 1823 seria sempre presidido por ele), quanto no seu principal objetivo de propor, discutir e deliberar sobre "os negócios mais interessantes das suas Províncias" (art.81). Sob a restrição que o mesmo órgão não poderia decidir sobre "interesses da nação", de outras províncias, e da Câmara dos Deputados e do executivo, restava uma definição muito geral e imprecisa de suas atribuições. No entanto, já estava previsto na Carta que os "negócios" que começassem nas Câmaras municipais seriam remetidos oficialmente ao secretário desse Conselho Geral para ali serem discutidos e encaminhados às autoridades superiores. Todas as resoluções do Conselho teriam que ser remetidas, por intermédio dos presidentes, diretamente ao poder executivo ou à Assembléia Geral, quando esta estivesse reunida, para serem aprovados. Como veremos a seguir, sua instituição foi interpretada entre os deputados como um contraponto necessário à ação dos "delegados do Imperador", já que ficara previsto que seu estabelecimento só se daria após a criação de um regimento específico.

\section{Os debates para regulamentação da administração nas províncias}

Quando se iniciaram os trabalhos do Parlamento no Brasil em 1826, em nome da legitimidade constitucional do regime após repressão violenta aos movimentos que se opuseram à outorga da Constituição, o clima de expectativa era grande. No que tocava às províncias, valia a lei de 20 de outubro de 1823 e o Imperador já nomeara seus primeiros presidentes desde o juramento da Carta. 0 deputado Raimundo José da Cunha Mattos, eleito por Goiás, foi o primeiro a falar em uma urgente necessidade de se organizar um regimento para o governo dos seus presidentes, para o que fez uma indicação. ${ }^{30}$ Dias depois, o mesmo deputado apresentou um projeto para 
31

Annaes do Parlamento Brasileiro. Câmara dos Deputados. Sessão de 1826. Rio de Janeiro: Typographia do Imperial Instituto Artístico, 1874 (APB-CD 1826), t. 1, 17 de maio, p.73-4.

32

Ibidem, 22 de maio.

33

Ibidem, 11 de julho.

34

Ibidem, 17 de maio, p.117-8.

\section{5}

Annaes do Parlamento Brasileiro. Câmara dos Deputados. Sessão de 1827. Rio de Janeiro: Typographia do Imperial Instituto Artístico, 1875, (APB-CD 1827), t.3, 07 de julho, p.80-4. A proposta tratava do funcionamento cotidiano da instituição, da forma de se constituir as sessões, das propostas, das comissões, das votações, das pessoas empregadas e de seu poder de polícia.

36

Annaes do Parlamento Brasileiro. Câmara dos Deputados. Sessão de 1827. Rio de Janeiro: Typographia do Imperial Instituto Artístico, 1875, (APB-CD 1827), t.4, 18 de agosto, p. 191-2.

37

Ibidem, p.192.

38

Pronunciamento de Antônio Ferreira França. Ibidem, p.336-7.

39

Annaes do Parlamento Brasileiro. Câmara dos Deputados. Sessão de 1828. Rio de Janeiro, Typographia do Imperial Instituto Artístico, 1876 (APB-CD 1828), t.1, 10 de maio, p.38-43. regimento da mesma autoridade executiva no qual se detalhavam suas atribuições, criava-se um conselho privativo, apenas consultivo, para auxiliá-lo, e thes retirava o poder de demitir magistrados e comandantes de armas, mesmo em conjunto com seus conselheiros. ${ }^{31}$ Após uma segunda leitura, o projeto foi encaminhado para a comissão de leis regulamentares ${ }^{32}$ e, depois disso, não voltou mais a aparecer no plenário.

Dois meses depois, foi a vez de Diogo Antônio Feijó, então deputado por São Paulo, apresentar um extenso projeto para governo das províncias em que estabelecia regimentos para vários cargos e instituições. ${ }^{33} \mathrm{Em}$ relação ao presidente, concebia-o como primeira autoridade provincial, um "inspetor" do cumprimento das leis, sem nenhum poder de intromissão nas atribuições dos outros órgãos (inclusive para sua demissão). A especificidade da proposta estava em atribuir aos Conselhos Gerais criados pela Carta de 1824 o direito de obter, quando seus membros considerassem necessário, esclarecimentos sobre as deliberações feitas pelos presidentes, numa clara forma de controlar sua ação. 0 texto foi remetido à comissão de leis regulamentares e, no ano seguinte de 1827, quando voltou ao plenário, sua discussão foi momentaneamente abortada. ${ }^{34} \mathrm{~A}$ justificativa era que se deixasse, por ora, a questão de lado em prol da regulamentação das Câmaras e dos juizes de paz, assuntos mais urgentes. Além disso, os mesmos Conselhos Gerais ainda esperavam a aprovação de um regulamento para sua instalação e a sua discussão esteve diretamente relacionada com a normalização da ação presidencial. Assim, vejamos.

Em julho de 1826, os senadores apresentaram à Câmara dos Deputados um projeto que marcava as atividades dos Conselhos Gerais para que estes entrassem em funcionamento. ${ }^{35}$ Logo discutido, o texto foi aprovado com sugestões de emendas por parte dos representantes. No entanto, uma indicação feita pelo mineiro Bernardo Pereira de Vasconcellos semanas depois, mostra que senadores e deputados não se entenderam quanto ao teor das matérias emendadas. ${ }^{36}$ Sua proposta era que eles retirassem as mudanças que haviam inserido no projeto original, em especial uma, que marcava a inviolabilidade dos conselheiros quando no exercício de suas funções, já que a segunda Câmara se recusava a aprová-las. Em nome da urgência na instalação do órgão, evocava os "danos que est[ariam] sofrendo os povos das províncias por essa falta, estando, como estão, privados de um direito, que a constituição Ihes confere, e que ninguém Ihes pode tirar sem manifesto atentado à lei constitucional"37. 0 direito seria o de representação de seus interesses por meio do canal de eleição popular na formação dos Conselhos. Apesar de Vasconcellos reconhecer que a imunidade de seus membros seria essencial para emissão de suas opiniões, pedia que se abrisse mão dela apenas naquele momento.

Depois de ir à comissão de Constituição, a indicação do deputado mineiro foi rejeitada: os deputados defendiam as emendas feitas e sob o argumento de ser o "maior sacrifício" os conselheiros não serem invioláveis em meio às disputas políticas que exist[ia]m nas provincias. ${ }^{38} \mathrm{~A}$ maioria preferiu esperar por uma reunião entre as duas Casas, conforme fórmula marcada pela Carta, para resolver a questão. Passados dois anos sem que isso acontecesse, o deputado pernambucano Manoel Caetano de Almeida e Albuquerque apresentou idêntica indicação àquela de Vasconcellos, para que o regimento dos Conselhos Gerais fosse aprovado, ainda que interinamente, em nome de sua instalação imediata. ${ }^{39} \mathrm{~A}$ justificativa geral era também a mesma: as "províncias est[ariam] privadas de um remédio 
40

Coleção das Leis do Império do Brasil de 1828. Rio de Janeiro: Imprensa Nacional, 1887, parte I.

41

É importante lembrar que os Conselhos de Presidência, também chamados do Governo, que funcionavam de acordo com a lei de 20 de outubro de 1823, se reuniriam uma vez ao ano "no tempo que aprouver ao mesmo Conselho, à vista das circunstâncias locais". Pela mesma lei, sua sessão ordinária não duraria mais de dois meses, mas que poderia ser convocado extraordinariamente sempre que o presidente assim solicitasse. No caso dos Conselhos Gerais de Províncias, era a Carta de 1824 (capitulo V) que marcava que as sessões durariam dois meses podendo ser prorrogadas, se necessário; seus trabalhos se iniciariam no dia 01 de dezembro de cada ano (art.80). Seus membros (em número de 21 para as Províncias mais populosas e 13 para as menos) também seriam eleitos da mesma forma que os "representantes da Nação".

\section{2}

Annaes do Parlamento Brasileiro. Câmara dos Deputados. Sessão de 1828. Rio de Janeiro, Typographia do Imperial Instituto Artístico, 1876 (APB-CD 1828), t.2, 03 de junho, p.16.

43

Ibidem, sessões de 14 e 16 de junho. indispensável" para seu governo, pois "sem Conselhos Gerais não haveria Constituição". Apesar dos posicionamentos contrários, que insistiam na necessidade de se preservar os conselheiros, a proposta foi aprovada quando Luiz Paulo de Araújo Basto, deputado pela Bahia, propôs uma emenda para que a Câmara tomasse igualmente a iniciativa de propor um outro projeto de regimento.

Em 27 de agosto de 1828, o Imperador dava sanção legal ao projeto de regimento para os Conselhos Gerais de Província da forma como ele havia sido proposto pelo Senado em $1826 .{ }^{40}$ A partir dai, eles passariam a ser criados nas capitais e funcionariam concomitantemente aos da presidência, em períodos ou em dias separados por existirem conselheiros eleitos para ambos. ${ }^{41}$ Nos seus cento e quinze artigos, ele marcava todas as etapas de funcionamento da instituição, desde as reuniões preparatórias, as atribuições do presidente e do secretário, a ordem das sessões no que tocava às propostas, discussões, instalação das comissões e modo de votar, estipulava as pessoas empregadas no seu serviço e também sua ação de polícia. Realmente não se estabeleciam direitos, como a inviolabilidade, a nenhum dos cargos envolvidos.

Em função disso, e como fora aprovado, os deputados investiram na proposição de um regulamento suplementar. Como texto alternativo, voltava ao plenário outra parte (título $\mathrm{V}$ ) do projeto apresentado por Diogo Antônio Feijó em 1826 e que se encontrava há dois anos na mesa dos trabalhos. ${ }^{42} \mathrm{~A}$ questão da ação dos presidentes de província apareceu logo no primeiro artigo, quando foi rapidamente aprovado que estes deviam prestar aos Conselhos, quando solicitados, esclarecimentos sobre o objeto de suas deliberações. De acordo com essa medida, decidiu-se também que os mesmos órgãos deveriam inquirir os funcionários públicos de qualquer graduação sobre queixas contra eles, além da controversa medida da inviolabilidade dos mesmos conselheiros eleitos (cuja responsabilidade só poderia ser julgada pela Assembléia Legislativa). 0 direito dos conselheiros receberem um "módico" subsídio, quando fosse necessário, também foi objeto de deliberação. Estava claro, portanto, que a votação pela proposta de Feijó caracterizaria os Conselhos Gerais como importantes esferas de poder local.

A inclusão de uma emenda de outro deputado paulista, Francisco de Pausa Souza e Mello, para que os Conselhos fiscalizassem a receita e a despesa provincial e enviassem anualmente um parecer diretamente à Assembléia Geral, aumentaria ainda mais as atribuições do órgão. 43 Tal função fazia igualmente parte do rol de competências do presidente da província, e entregá-la também aos conselheiros eletivos significava dotálos de controle financeiro nas localidades e, portanto, fortalecer seu papel político. 0 que comprova que a maioria dos representantes dessa primeira legislatura (1826-29) esteve realmente envolvida tanto em dar forma aos Conselhos para seu funcionamento como em fortalecê-los diante da autoridade presidencial. Mesmo que diretamente quase nada se tenha avançado em relação a um regimento para os próprios presidentes, era evidente que se concebia que a ação de uma instituição provincial eletiva seria uma forma de cerceamento de eventuais atitudes despóticas por parte dos "delegados do Imperador". Dessa forma, o projeto foi encaminhado para o aval dos senadores.

A análise dos debates para o ano de 1830 no que toca às províncias permite que se vislumbre idêntica tendência normativa na concepção de seu governo desde o início da segunda legislatura (1830-33). Antes de mais 
Annaes do Parlamento Brasileiro. Câmara dos Deputados. Sessão de 1830. Rio de Janeiro: Typographia do Imperial Instituto Artístico, 1878 (APB-CD 1830), t.1, 26 de maio, p. 235-7.

45

Ibidem, p. 236

46

Ibidem, 26 de maio, p.237.
47

Ibidem, p.237-8. nada, a pressão pela realização de um regimento para os presidentes voltou à cena. Dias após a abertura dos trabalhos, foi o mesmo Feijó que, reeleito, colocou novamente sua importância, e reapresentou, com algumas modificações, parte do projeto que fizera em 1826. ${ }^{44}$ Argumentou que os "presidentes s[eriam] verdadeiramente absolutos" e que eles, deputados, em cinco anos, não haviam feito nada para contê-los. Pedia também a urgência para a matéria. 0 baiano Lino Coutinho foi quem mais enfaticamente apoiou a proposta, segundo ele, porque os presidentes "até hoje t[eriam] obrado segundo seu arbitrio sem conservar lei alguma"45. 0 pernambucano Luiz de Paula Cavalcanti e Albuquerque iria até mais longe ao defender a importância da lei e taxar o próprio Feijó de "anticonstitucional" pela associação do presidente a um "imperador da província", quando ele não passaria de seu "administrador"46. A despeito das críticas, a urgência foi aprovada e decidiu-se pela nomeação de uma comissão especial para tratar do tema.

Na mesma sessão, imediatamente após a votação acerca do regimento dos presidentes, voltou-se a discutir, dois anos depois, o projeto dos deputados que marcava as atribuições dos Conselhos de províncias, agora com as emendas feitas pelos senadores. Vale dizer que todas as mudanças propostas pela segunda Casa foram negadas sob a justificativa geral de que elas diminuiam o poder dos Conselhos Gerais e evitavam que os presidentes se submetessem a eles, visivelmente fortalecidos com a proposta original de Feijó. Contra todas as alterações falou o paulista Martim Francisco Ribeiro de Andrada que sempre se destacou por posições políticas especialmente moderadas:

As atribuições dos Conselhos de província versam sobre tudo que for de utilidade provincial. Será de utilidade provincial conhecer da violação da lei perpetrada pelo presidente da província? Indubitavelmente. Se [for] uma atribuição do Conselho da província, cuidar do que é útil, como o Conselho da província não pode tomar disso conhecimento, ouvindo as autoridades contra quem se reclama? Como não se quer que se ouça o presidente? ${ }^{47}$

Com justificativas semelhantes, a opinião de que os presidentes deveriam prestar esclarecimentos aos Conselhos foi predominante. Ainda que timidamente, alguns deputados se colocaram contrários, sob o argumento de que apenas ao tribunal de justiça caberia autoridade para entrar no mérito da questão. A vitória do texto original, nos moldes como havia sido votado em 1828, foi tranqüila e não deixava dúvida sobre a tentativa de se consolidar os Conselhos Gerais como verdadeiros órgãos de poder locais. Mantida a incompatibilidade de posição entre as duas Casas legislativas, 0 projeto não voltaria à cena; muito provavelmente também porque entraria em discussão, no ano seguinte, uma reforma da Constituição que tocaria, entre outras, na questão dos governos provinciais. Idêntico motivo explica o desaparecimento do texto do regimento para os presidentes que também sumiria do plenário na mesma legislatura.

Mas antes disso, ainda no ano de 1830, outra decisão favorável ao fortalecimento dos Conselhos tomaria forma, corroborando nossa idéia central. Ela aconteceu após a enunciação da seguinte polêmica: como deveriam ser discutidas as propostas encaminhadas pelos órgãos provinciais ao Rio de Janeiro? Instalados há dois anos, já era grande o número de suas distintas representações à Assembléia, inexistindo um critério único de tratamento dado a elas. A polêmica iniciou-se quando esteve em pauta 
Annaes do Parlamento Brasileiro. Câmara dos Deputados. Sessão de 1830. Rio de Janeiro: Typographia do Imperial Instituto Artístico, 1878 (APB-CD 1830), t. 1, 17 de maio, p.158.
49

Ibidem.

50

Ibidem, p.159.

51

Ibidem, 10 de julho. um projeto do Conselho da Bahia (sobre moedas de cobre falso) e alguns deputados demonstraram dúvidas sobre como propor modificações ao seu texto original. ${ }^{48}$ Nesse momento, o mineiro José Antônio da Silva Maia questionou o tratamento dado aos textos oriundos das províncias, sugerindo ser conveniente que, para além de uma discussão geral, houvesse uma outra, em que se pudesse tratar de cada um dos artigos em particular. Sua posição gerou grandes discordâncias.

0 pernambucano Luiz Francisco de Paula Cavalcanti e Albuquerque defendeu idéia que sairia vencedora, depois de longuíssimo debate. A argumentação era que os deputados não poderiam emendar nenhuma das propostas vindas dos Conselhos Gerais, por dois motivos: por uma questão de economia de tempo da Câmara - pois que as matérias já teriam sido discutidas no âmbito de suas localidades -; e porque esses órgãos tratavam de "coisas cíveis e peculiares da sua província, não de coisas políticas", bastando rejeitá-las ou aprová-las. ${ }^{49}$ No mesmo sentido, Lino Coutinho foi taxativo ao enfatizar que eles não poderiam alterar o teor dos projetos enviados, bastando rejeitá-los no caso dos mesmos transcenderem a esfera provincial. Além disso, afirmava que o trabalho dos Conselhos apresentava muita similaridade com o do legislativo:

\footnotetext{
Se, pois, a proposta não envolve nenhuma das matérias de que falo [de negócios gerais], a Câmara não faz mais do que aprovar, porque a constituição mandou que aquela espécie de pequeno corpo legislativo legislasse sobre os interesses particulares da província, e nós apenas somos censores; por isso que a Constituição diz que devem as propostas ser aprovadas com uma única discussão. 50
}

Deve-se notar que por trás de uma aparente formalidade estava em jogo a possibilidade de, no caso de serem aprovadas as propostas sem modificações, os Conselhos Gerais de provincia exercerem papel importante na proposição e determinação das leis. 0 mesmo Luiz Cavalcanti chegou a defender, sem sucesso, que os projetos elaborados nessas instâncias deveriam ser remetidos por esses mesmos órgãos, sem intermédio do presidente, valorizando-os como esferas de representação.

Os opositores da proposta não foram poucos, a acusavam de fornecer, de forma anticonstitucional, poder legislativo às provincias, e defendiam que os textos dos Conselhos fossem considerados como os demais projetos (ou seja, que sofressem emendas e passassem por três discussões). A votação final apertadissima comprova a divisão de opinião entre os deputados. ${ }^{51}$ Sua aprovação foi vista como uma vitória da representação dos interesses da província já que, a despeito de ficar assegurado à Assembléia o direito de vetar seus projetos, a impossibilidade de se fazer emendas evitaria que se pudesse alterar seus conteúdos. Ainda mais se lembramos que aos presidentes não cabia nenhum poder de sanção, mesmo que temporária, sobre as matérias aprovadas nesses órgãos.

Das discussões analisadas, deve-se concluir que, na prática legislativa do Primeiro Reinado, predominou uma concepção normativa em relação aos poderes das províncias que tanto pretendeu controlar a ação dos "delegados do Imperador" como o fez a partir da tentativa de fortalecimento da instância representativa nas localidades. Esta era, sem dúvida, uma leitura peculiar da Constituição, em especial do seu artigo 81 que fornecia aos Conselhos Gerais o "principal objeto de propor, discutir e deliberar sobre os negócios mais interessantes das suas províncias". Nestes termos falou o 


\section{2}

Annaes do Parlamento Brasileiro. Câmara dos Deputados. Sessão de 1830. Rio de Janeiro: Typographia do Imperial Instituto Artístico, 1878 (APB-CD 1830), t. 1, 23 de junho, p. 475.

53

MATTOS, IImar Rohloff. La experiencia del Imperio del Brasil. In: ANNINO, Antonio (et. alli), De los imperios a las naciones: Iberoamerica. Ibercaja/ Obra Cultural, 1994. Segundo o autor, foi quando liberais da estirpe de Evaristo da Veiga e Bernardo Pereira de Vasconcellos viram na possibilidade de reforma "um instrumento privilegiado para deter a revolução" (p. 512).

54

SLEMIAN, Andréa. Sob o império das leis: Constituição e unidade nacional na formação do Brasil (1822-1834). 2006. Tese (Doutorado em História Social). Faculdade de Filosofia, Letras e Ciências Humanas, Universidade de São Paulo, São Paulo, 2006. cap. 2.

55

A comissão era formada por Francisco de Paula Souza (São Paulo), José Cesário de Miranda Ribeiro (Minas Gerais) e Francisco de Souza Paraiso (Paraiba do Norte). Annaes do Parlamento Brasileiro. Câmara dos Deputados. Sessão de 1834 (APB-CD 1834). Rio de Janeiro: Typographia de Hypollito José Pinto e \& Cia, 1879, t.1, documento A. Antes e depois de lido esse parecer, vários projetos de reforma foram apresentados por outros deputados.

56

Annaes do Parlamento Brasileiro. Câmara dos Deputados. Sessão de 1834 (APB-CD 1834). Rio de Janeiro: Typographia de Hypollito José Pinto e \& Cia, 1879, t.1, documento C. paraibano Joaquim Manoel Carneiro da Cunha, na discussão sobre o tema no ano de 1830:

Alguns Srs. deputados disseram que isto era um sistema de confederação; mas já se respondeu que se o é, a Constituição é que os determina e não é esse artigo [81] da nossa constituição o mais liberal, o mais franco? Quando li a Constituição oferecida, olhando para os seus artigos, logo que li este dei o meu voto: dele hão de emanar todos os bens que nos hão de resultar, demos pois a estes Conselhos as suas atribuições, não thas roubamos. 52

A associação entre autonomia das províncias e o fortalecimento dos Conselhos ficava aí evidente, já que Cunha estava entre seus defensores. Não à toa, fora também aprovado pelos deputados que essas instituições verificariam os excessos dos presidentes; medida que, sem nunca ter entrado em prática efetivamente, evidenciava existir maioria entre os legisladores em torno da necessidade de criação de mecanismos para seu controle.

\section{A reforma da Constituição e a consolidação da autoridade do presidente da província}

Quando a possibilidade de reforma da Constituição pôs um freio no afã revolucionário que reinava após a Abdicação em 183153, a questão de uma nova organização dos poderes nas províncias esteve na sua esteira. Nessa época, o funcionamento da administração nas localidades era centrado na ação dos presidentes a despeito da instalação dos Conselhos Gerais em todas as capitais que, pelo envio contínuo de propostas à Corte, exerciam uma função de representação local sem interferência direta sobre o agente executivo. ${ }^{54}$ Desde então, projetos para mudança da Carta de 1824 entraram em pauta na Câmara dos Deputados, e sua discussão tocou diretamente no nivel de autonomia das partes do Império e definição dos papéis das suas autoridades. Por essa razão, vale à pena analisar as mudanças no nosso objeto central tendo em vista a viabilização da própria reforma.

Como é sabido, a saída do Imperador acarretaria um fortalecimento da instância de representação nacional em relação ao executivo central, agora exercida por uma Regência trina. Por essa razão, logo na abertura dos trabalhos legislativos apareceram os clamores para transformação das bases político-institucionais da nação, mimetizados pela Constituição. Uma comissão foi então nomeada para elaboração de um projeto de reforma, apresentada no plenário em sessão de oito de julho de 1831 e com a proposição de mudanças significativas. 55 Previa-se a supressão do poder moderador, a instituição de um regente único, a formação de um Senado eletivo (não mais hereditário), e a substituição dos Conselhos Provinciais por Assembléias Legislativas locais que cuidariam dos assuntos internos das províncias. Apesar disso, o governo central continuaria a ser responsável pela escolha dos presidentes de províncias, os quais, pelo projeto, passariam a ter direito de sanção das leis nos mesmos moldes que competia ao Imperador quanto às leis feitas pela Assembléia Nacional.

Depois de ampla discussão, concentrada entre agosto e setembro, aprovou-se um projeto geral de reforma, mais conciso e radical do que se havia então proposto. 56 Eram doze itens que previam: a transformação do governo do Brasil numa "monarquia federativa"; o reconhecimento de apenas três poderes políticos (as atribuições do moderador que fossem "conveniente conservar" passariam para o executivo); um Senado eletivo e temporário; a diminuição do tempo da legislatura para dois anos; a 
MOREL, Marco. As transformações dos espaços públicos. Imprensa, atores políticos e sociabilidades na cidade imperial (1820-1840). São Paulo: Hucitec, 2005. passim; BASILE, Marcelo. O Império em construção: projetos de Brasil e ação política na Corte Regencial. 2004. Tese (Doutorado em História), Universidade Federal do Rio de Janeiro, Rio de Janeiro, 2004.

\section{8}

$\mathrm{Na}$ imprensa, inclusive naquela considerada moderada, essa posição teve divergências. Conforme cita Marcelo Basile, O Império em construção: projetos de Brasil e ação politica na Corte Regencial. 2004. Tese (Doutorado em História), Universidade Federal do Rio de Janeiro, Rio de Janeiro, 2004. p.63, o periódico $O$ Independente (em 15/07/1831), reticente em relação às reformas, chegou a apoiar medida defendida pelos exaltados de eleição direta para os presidentes de província, justificando sua aceitação por entender que seria inevitável o conflito nas províncias entre o legislativo eleito pelo povo e o executivo com poder de veto sobre aquele.

\section{9}

De acordo com a Constituição de 1824 (artigos 174-7), mudanças no seu texto só poderiam ter lugar a partir de indicação da Câmara dos Deputados de quais artigos seriam reformáveis para, depois de aprovada pelo senado e pelo imperador, a legislatura seguinte fazer a reforma propriamente dita.

\section{0}

No decorrer desse mês o clima geral era tenso, tanto pela demora do Senado em emitir suas emendas ao projeto, como pelas discussões que giravam em torno da saída de José Bonifácio como tutor. Diante de uma série de impasses, os ministros em bloco decidiram abandonar os cargos e, em finais de julho, a Regência encaminhou seu pedido de demissão à Câmara. Então se interromperam os trabalhos enquanto uma comissão especial, para isso escolhida, avaliava o caso. Horas depois, esta apresentou um parecer com a proposta para que "esta augusta câmara se converta em assembléia nacional, para então tomar as resoluções que requer a crise atual" e fazer imediatamente a reforma. A reação contra a proposta foi rápida, encabeçada pela posição moderada do deputado Honório Hermeto Carneiro Leão, futuro Marquês do Paraná, em nome da defesa da Constituição como nossa única "tábua de salvação". Esse episódio ficou conhecido na historiografia como uma tentativa de "golpe de Estado"; ver "Breve noticia histórica" in Annaes do Parlamento Brasileiro. Sessão de 1832. Câmara dos Deputados. Rio de Janeiro: Typographia do Império Instituto Artístico, 1875, t. 2; e CASTRO, Paulo Pereira. A experiência republicana. In: HOLANDA, Sérgio Buarque de (org.). História Geral da Civilização Brasileira. Tomo II: 0 Brasil monárquico. Vol. 2: 0 processo de emancipação. São Paulo: Difusão Européia do Livro, 1967; BONAVIDES, Paulo e ANDRADE, Paes de. História Constitucional do Brasil. Rio de Janeiro: Paz e Terra; BARBOSA, Silvana Mota Barbosa. A Sphinge Monárquica: o poder moderador e a política imperial. 2001. Tese (Doutorado em História). Unicamp, Campinas, 2001. cap. 3. supressão do Conselho de Estado; e a citada conversão dos Conselhos de Províncias em Assembléias Legislativas Provinciais. A proposta mantinha o poder dos presidentes de província de sancionar, mesmo que suspensivo mediante a apresentação das razões por escrito, às leis feitas nas Assembléias locais.

A aprovação do citado texto pelos deputados foi uma expressão do clima de radicalismo político então vivido em que, sobretudo na imprensa e nas ruas, a mobilização por significativas transformações esteve, mais do que nunca, na ordem do dia. ${ }^{57}$ Nesse sentido, é evidente como o projeto apostava no fortalecimento das instâncias legislativas, sobretudo provinciais, a contrapelo do peso dado ao executivo pela Constituição, a partir de uma das bandeiras mais defendidas naquele momento: a da "federação". Daí, se a proposta tendia a contemplar proposições dos exaltados no tocante à autonomia das províncias, o poder do presidente seria compensado com o direito de sanção ao legislativo local (que inexistia para o caso das medidas aprovadas pelos Conselhos Gerais), o que Ihes permitiria continuar como figuras centrais na administração. 580 que comprova que, do ponto de vista normativo, a estruturação dos poderes provinciais no projeto obedecia à mesma concepção normativa por nós enunciada.

0 texto seria encaminhado aos senadores 59 , cujas emendas só entrariam no plenário no ano seguinte de 1832, logo após a Câmara ter vivido um momento de extrema tensão com a tentativa frustada de implantação de uma Assembléia Constituinte no final de julho. 60 As alterações eram quatorze no total, com a supressão dos parágrafos tidos como mais radicais (acerca da monarquia federativa, do fim do poder moderador e do Senado hereditário), e a indicação dos artigos que deveriam ser reformados. 61 Depois de uma esperada recusa por parte dos deputados, as duas Casas se reuniram para deliberar sobre a questão. 0 resultado foi um projeto de reforma - que deu origem à lei de 12 de outubro de 1832 - muito mais moderado pela ação dos senadores, que fornecia aos deputados da legislatura seguinte o direito de reformarem apenas os artigos indicados. $E$ embora o governo das províncias estivesse entre os pontos a serem alterados, não se tocava diretamente no poder dos presidentes.

A lei de 12 de outubro de 1832 balizou a discussão da reforma que só se iniciaria dois anos depois com a abertura da terceira legislatura (183437), dotada de poderes para alterar a Constituição. Nessa época, o clima geral de expectativa pelas transformações do regime era bem mais comedido do que após a Abdicação, e a Câmara colocou em prática seu papel de moderação na realização das alterações. Dessa forma, uma comissão especial elaborou um projeto final de reforma da Constituição ${ }^{62}$ que, apresentado em junho, sofreria poucas alterações no seu conteúdo geral. Nele, os artigos concentravam-se na criação das Assembléias Legislativas locais no lugar dos Conselhos existentes nas províncias, sem tocar diretamente nas bases de sustentação da política imperial. Aos presidentes era corroborado o poder de sanção sobre as leis, ainda que temporário63, e detalhadas sete atribuições que incluiam, basicamente, a nomeação de empregados públicos e de conselheiros privativos a ele, além do aval para convocar a Assembléia a se reunir no prazo marcado, e mesmo extraordinariamente. Previa-se também a extinção do Conselho de Estado.

Apesar de um consenso ter sido construído entre uma maioria de deputados que garantiu a aprovação de grande parte do projeto, opiniões críticas contundentes evidenciam a dificuldade na construção de uma 
Annaes do Parlamento Brasileiro. Câmara dos Deputados. Sessão de 1834. Rio de Janeiro: Typographia de Hypollito José Pinto e \& Cia, 1879, (APB-CD, 1834), t.1, documento F.

\section{2}

A comissão era composta por Francisco de Paula Araújo e Almeida (Bahia), Bernardo Pereira de Vasconcellos (Minas Gerais), e Antônio Paulino Limpo d'Abreu (Minas Gerais); Annaes do Parlamento Brasileiro. Câmara dos Deputados. Sessão de 1834. Rio de Janeiro: Typographia de Hypollito José Pinto e \& Cia, 1879, (APB-CD, 1834), t.1, 07 de junho, p.104-6.

\section{3}

A sanção funcionaria da seguinte maneira: se o presidente negasse a aprovação sobre qualquer lei, ela voltaria à Assembléia Legislativa provincial e seria submetida a uma nova discussão. Sendo ou não adotadas as razões do veto, o presidente seria obrigado a sancionar a matéria se ela fosse então novamente aprovada, agora por dois terços de seus membros. Trata-se do artigo 15 do projeto, assim aprovado no Ato Adicional.

\section{4}

Annaes do Parlamento Brasileiro. Op. Cit. , sessões de 23 a 28 de junho.

\section{5}

Ibidem, 23 de junho, p. 169. discurso de Antônio Joaquim de Melo, deputado por Pernambuco.

66

Ibidem, sessões de 25 e 26 de junho.

67

Ibidem, 25 de junho, p.176.

\section{8}

0 deputado já havia sido eleito, pela sua provincia natal, para as duas primeiras legislaturas da Assembléia Geral.

\section{9}

Annaes do Parlamento Brasileiro. Op.Cit., t.1, 30 de junho, p.205-6; e t.2, 01 de julho, p.8.

70

A justificativa para existência de um sistema bicameral era que à segunda Câmara caberia o papel de controlar os possiveis excessos advindos das decisões dos representantes diretos. alternativa comum para todas as partes do Império. A primeira polêmica que se instaurou entre os deputados foi no tocante aos poderes das novas Assembléias provinciais. Os críticos à configuração final da proposta, eram contrários a que se marcasse ponto por ponto as atribuições das Assembléias sob o argumento de que os Conselhos Gerais desfrutavam de maiores atribuições ao terem direito de deliberar sobre quaisquer negócios de interesse local.64 Eles defendiam, no geral, que ambos os órgãos aparecessem como sinônimos. Os que apoiavam o texto da comissão apostavam no fato de que as novas Assembléias teriam um diferencial qualitativo no seu direito de "legislarem no rigor dessa palavra, isto é, a ser a legislação provincial completamente concluida na provincia"65, e assim foi aprovado.

A discussão seguinte, de um artigo que especificava o número de membros das Assembléias, é demonstrativa de uma das principais polêmicas existente na Casa. A contestação ao projeto era feita à premissa de que apenas uma lei feita na Corte poderia diminuir ou aumentar as cadeiras dos representantes locais. 66 Sob a acusação de se pretender "centralizar e tiranizar" o Brasil, foi o padre Venâncio Henriques de Resende (o qual já havia sido deputado Constituinte em 1823, e também na segunda legislatura) que fez um dos ataques mais eloqüentes à proposta. 0 pernambucano defendeu inclusive um principio ainda mais radical: que ficasse a cargo de cada uma das províncias entrar na reforma da Carta de 1824 ou permanecer na condição política como estava até o momento.67 Em suas palavras, "guardando-se a fisionomia da monarquia, tudo o mais se deveria deixar livre às circunstâncias da localidade". A despeito de vários outros deputados pronunciarem-se a favor da mudança, novamente venceria o texto tal qual proposto.

Aparentemente banal, a polêmica escancarava a tensão existente entre os representantes quando o tema era a equação de poderes entre as partes do Império e, portanto, dos níveis da autonomia provincial. Nesse momento, a despeito da já apontada dificuldade em se falar em bancadas regionais coesas, foram predominantemente os deputados do Norte que falaram contra o projeto apresentado pela comissão com o intuito de garantir uma menor ingerência da Corte nos negócios locais. Daí a esfera de ação dos presidentes ser um dos pontos nodais para construção de um novo arranjo institucional inperial; nesse sentido, o texto da reforma tanto não colocava em xeque a existência de sua autoridade, como referendava-a com um rol de atribuições. Mas ainda assim, várias foram as tentativas de mudança das leis sobre o cargo.

A primeira delas apareceu na fala de Hollanda Cavalcanti de Albuquerque, reeleito pela província de Pernambuco68, que se colocou frontalmente contrário ao direito do presidente prorrogar as sessões das Assembléias (artigo 8 do projeto).69 Seu argumento era que os homens escolhidos pela Corte "não poder[iam] saber mais dos interesses das províncias do que seus próprios representantes", e que se criaria um "quinto poder" se thes fosse concebido este "poder soberano" de influir nos trabaIhos legislativos. 0 mesmo deputado chegaria a defender a total exclusão dos presidentes da administração, lugar em que desempenhariam um papel semelhante ao dos antigos capitães generais, deixando à sua alçada apenas "questões externas" e do "movimento das forças de mar e terra". A defesa do artigo foi feita em nome da existência de uma força local que pudesse conter os excessos da Casa legislativa, como reprodução do esquema que funcionava no governo central, com o agravamento de não existir uma câmara vitalícia local. ${ }^{70}$ Assim também foi aprovado. 
71

Annaes do Parlamento Brasileiro. Câmara dos Deputados. Sessão de 1834. Rio de Janeiro: Typographia de Hypollito José Pinto e \& Cia, 1879, (APB-CD, 1834), t.2, 05 de julho, p. 34-6.

72

Ibidem, 07 de julho, p. 38.

73

Ibidem. Fala de Antonio Joaquim de Mello, deputado por Pernambuco.

\section{4}

Ibidem, 08 de julho, p.49.

75

Ibidem.

76

Ibidem, 09 de julho, p.58.

77

Ibidem, 08 de julho, p.59.
Outra tentativa de controle das atribuições dos presidentes foi feita por Francisco Álvares Machado de Vasconcellos, representante por São Paulo, quando estava em pauta se as Assembléias poderiam decretar a suspensão dos magistrados que tiverem acusações de crimes de responsabilidade. 0 deputado então fez uma emenda para que as mesmas Assembléias pudessem decretar a suspensão do presidente se este fosse igualmente denunciado. ${ }^{71}$ Seu argumento era claro:

Conservando-se os presidentes no estado em que eles atualmente se acham, não dando às províncias senão o direito de representar contra eles, em muito risco ficará a liberdade do Brasil. $^{72}$

Ou seja, caberia à instância legislativa uma ingerência sobre o presidente. Tal proposta foi rejeitada e a justificativa geral era que se as ações do "único delegado monárquico nas províncias" dependessem "da vontade e supremacia da assembléia legislativa, elemento democrático", o governo monárquico desapareceria nas localidades. ${ }^{73}$

No momento que entrou em discussão o poder de sanção do presidente, a mesma tensão reapareceu. Foi quando o maranhense Antonio Pedro da Costa Ferreira, numa tentativa de mediar os ânimos, sustentou uma emenda para que os "delegados do Imperador" somente reunidos com seu conselho tivessem direito de sancionar leis. ${ }^{74}$ Nessa hora, Evaristo Ferreira da Veiga, deputado por Minas Gerais, defendeu longamente o veto independente - ainda que suspensivo - do presidente enquanto "delegado" e "expressão da vontade nacional"75. Esse foi igualmente aprovado. Posteriormente decidiu-se por outra emenda que o impossibilitava de ter sanção em matérias relativas aos empregos e contribuições municipais, a legislação civil, judiciária e eclesiástica da provincia (artigo 13 do Ato Adicional). A pretensão da medida era restringir à esfera da administração a área de influência legislativa da autoridade presidencial, e, nestes termos, a alteração teve respaldo.

Uma evidente tentativa de fazer com que a escolha dos presidentes fosse também influenciada pelas províncias em detrimento da escolha do Imperador ocorreu quando se discutiram especificamente suas atribuições. Foi quando, sem ter relação direta com a proposta geral desses artigos, Antonio Fernandes da Silveira, deputado por Sergipe, propôs uma emenda para que os mesmos presidentes fossem nomeados pelo Imperador a partir de uma lista tríplice organizada pelas Assembléias provinciais. ${ }^{76}$ Aprovouse que, mesmo sem estar na ordem das matérias, a proposta entraria em discussão; a qual, aliás, não seria pequena.

Aqueles favoráveis à emenda de Silveira defendiam uma maior participação dos "povos" na eleição de seus representantes, e aproveitavam para criticar o fato do Conselho privativo proposto para o presidente não ser mais eletivo (como ainda funcionava de acordo com a lei de 20 de outubro de 1823). 0 já citado Costa Ferreira, nesse momento, atacou de frente a função da autoridade presidencial sob a alcunha de "bachá", e acusou de centralização deixar sua escolha exclusivamente ao Imperador. ${ }^{77}$ Igualmente entre outros que defenderam a matéria, a crítica não era somente à questão da ingerência do monarca, mas também ao amplo poder que o cargo desfrutava, por mais que isso não estivesse em discussão. As opiniões contrárias à alteração apelavam, sobretudo, para o caráter da monarquia e decorrente necessidade de existir uma influência do poder central nas 
78

Annaes do Parlamento Brasileiro. Câmara dos Deputados. Sessão de 1834. Rio de Janeiro: Typographia de Hypollito José Pinto e \& Cia, 1879 (APB-CD, 1834), 12 de julho, p.79-80.

79

Essa discussão foi base do meu trabalho de doutoramento; SLEMIAN, Andréa. Sob o império das leis: Constituição e unidade nacional na formação do Brasil (1822-1834). 2006. Tese (Doutorado em História Social). Faculdade de Filosofia, Letras e Ciências Humanas, Universidade de São Paulo, São Paulo, 2006. Ver Introdução.

80

Annaes do Parlamento Brasileiro. Op. Cit. , t.2, 04 de agosto, p.186-7.

81

Ibidem, p.187-9. províncias que, pela emenda, ficariam por demais autônomas. Apesar do debate, a votação comprovou que já poucos aderiram à matéria, que perdeu de 11 a 77 votos. 78 Os presidentes continuariam, como desde a criação do cargo, eleitos pelo Imperador, agora também com poder de sanção.

Como é sabido, a reforma seria promulgada como Ato Adicional, em 12 de agosto, e a definição do arranjo institucional por ela proposta para as províncias manter-se-ia por todo o Império. Ainda que moderada face à expectativa de transformação da ordem vigente que veio à tona após a Abdicação, sua aprovação seria um marco por duas principais razões: pelo fortalecimento provincial enquanto uma unidade autônoma e, ao mesmo tempo, pela instituição definitiva da Corte como centro de uma estrutura normativa que tinha os Estados liberais como paradigma. ${ }^{79}$ De alguma forma, essas duas facetas estiveram também presentes no resultado final legislativo do ano de 1834 quando, após a criação das Assembléias Legislativas locais, finalmente aprovou-se um regimento para os presidentes de província, no qual seus poderes foram igualmente ampliados.

0 fato é que, com o Ato Adicional, a lei de 20 de outubro de 1823, que instituira de forma provisória um governo para as províncias e também marcara algumas atribuições dos presidentes, foi revogada. Esta era até então a única norma que regulamentava a jurisdição presidencial durante todo o Primeiro Reinado, a despeito das várias tentativas entre os deputados de se promover uma nova, conforme se discutiu aqui. Com a aprovação da reforma, foram agregadas algumas funções aos "delegados do Imperador" - a de convocar a Assembléia Provincial, de suspender a publicação de leis e de expedir ordens e instruções - com um significativo aumento de seu poder pessoal de decisão frente à nova instância representativa. Além disso, extinguiu-se seu Conselho privativo, cujo artigo foi suprimido do projeto inicial após contestação dos deputados.

No plano provincial, a supressão da lei de 1823, trouxe consigo a necessidade de uma demarcação efetiva da ação presidencial. Por isso, dias depois do término da sua discussão entre os deputados, os senadores enviaram à Câmara um texto em que propunham um regimento para os presidentes. ${ }^{80}$ Este logo entrou em discussão e foi rapidamente aprovado na sua quase totalidade, em não mais de quatro sessões. Tamanha rapidez tem ao menos duas explicações: o fato de, nos idos de agosto e setembro de 1834, os representantes estarem envolvidos na polêmica acerca do projeto de orçamento para o ano seguinte, o que consumiu tempo e energia de todos; e também a generalizada descrença de que, naquele momento, qualquer alteração de fundo pudesse realmente ser implementada já que a proposta conjugava-se bem com as bases da reforma já aprovadas. Não à toa, a disputa pelas rendas do orçamento pôde ser vista como mais importante para os interesses dos grupos que os deputados representavam.

Ainda assim, logo que entrou em pauta o primeiro artigo que afirmava ser o presidente a primeira autoridade da província, a qual todos se achariam subordinados, novamente voltou à tona a questão de que para sua escolha deveria concorrer, ao lado do monárquico, também o "elemento popular". Nessa linha, falaram Antônio e Cornélio Ferreira França - respectivamente pai e filho, representantes pela Bahia e opositores permanentes ao projeto apresentado pela comissão na discussão da reforma da Carta -, mesmo que a questão nem estivesse em discussão. 810 tema continuava a inspirar polêmica. 0 já citado Costa Ferreira fez uma emenda para que ao menos constasse no artigo que o presidente só poderia decidir sozinho 
82

Lei de 03 de outubro de 1834; Coleção das leis do Império do Brasil. Rio de Janeiro: Impressa Oficial, 1887. o que não fosse também atribuição dos conselheiros. Após várias manifestações, discursos e posições semelhantes às que se analisou ao longo do debate para as alterações constitucionais, não só a proposta de Costa Ferreira foi negada como aprovada outra, de Francisco de Paula Araújo, que isentava o município da Corte da autoridade do presidente da respectiva província. Dessa forma, estabelecia-se no regimento a autonomia administrativa do centro político do Império.

0 método de escolha do vice-presidente também gerou pronunciamentos contrários, mas, como em outras questões pontuais, em nada se alterou o texto. No entanto, duas inserções feitas pelos deputados reforçavam o sentido da autoridade presidencial. A primeira foi a definitiva extinção de um conselho de presidência novamente previsto; a segunda, de um parágrafo que atribuia ao mesmo presidente o poder temporário de decidir sobre conflitos de jurisdição entre as autoridades da província. Ambas deixavam claro que o "delegado do Imperador" poderia agir individualmente, sem consulta prévia a nenhuma instância, o que incluia a centralização, na sua figura, da mediação das tensões administrativas. Dessa forma, um dos principais papéis de árbitro que anteriormente ele desempenhava em comunhão com seus conselheiros ficaria restrito, a partir de então, a si mesmo.

0 texto foi sancionado como lei em outubro, sob a forma de um regimento para os presidentes. 82 Nela se definiam, para além de suas atribuições, os ordenados e ajudas de custo, a forma de escolha do vice-presidente a partir de lista aprovada pela Assembléia provincial e levada para a escolha do Imperador, a forma do juramento de ambas as autoridades diante da mesma Assembléia. Entre as funções presidenciais estavam: executar e fazer executar as leis, exigir dos empregados públicos as informações devidas, inspecionar todas as repartições, prover os cargos (inclusive provisoriamente aqueles de nomeação do Imperador), levar a efeito a ação de empregados gerais nos negócios provinciais, e também conceder licença aos funcionários. Além disso, seria sua obrigação participar ao governo todos os "embaraços" que encontrasse, e suspender qualquer empregado por abuso já que ele decidiria, mesmo que momentaneamente, os conflitos de jurisdição. Um dos parágrafos marcava que sua autoridade deveria estar à frente das Tesourarias provinciais (conforme fixara a lei de sua criação em 1831) sem deixar dúvida sobre o papel fundamental que teriam os presidentes na questão da arrecadação monetária da província e no envio de recursos ao centro do Império.

Em relação à lei de outubro de 1823, é visivel como o âmbito de ação individual prevista aos presidentes aumentava com o novo regulamento, sobretudo porque os seus conselhos privativos, ainda que apenas consultivos, foram definitivamente extintos. Nesse sentido, seguiu-se um caminho normativo um pouco distinto ao pretendido durante as legislaturas do Primeiro Reinado, quando predominara uma tendência em aumentar o poder dos então Conselhos Gerais da província como órgãos que poderiam, inclusive, exercer alguma forma de controle sobre a autoridade presidencial. Conforme vimos, tal arranjo acabou não sendo aprovado pelos senadores, e os que o defendiam apostaram, a partir de 1831, na reforma da Carta. No entanto, após várias propostas de transformação radical na forma de escolha dos presidentes, 0 saldo de toda a discussão de 1834 foi o fortalecimento de sua autoridade diante da novidade da criação de um espaço legislativo provincial. Nestes termos, a terceira legislatura na Câmara dos Deputados, responsável pela aprovação final da reforma, foi menos ousada do que a anterior. 
83

Refiro-me aqui ao conjunto de medidas modernizadoras do aparato público colocadas em prática durante as duas primeiras legislaturas, analisadas por BARMAN, Roderick. Brazil. The forging of a nation 1798-1852. Stanford: Stanford University Press, 1988; LOPES, José Reinaldo de Lima. Iluminismo e jusnaturalismo no ideário dos juristas da primeira metade do século XIX. In: JANCSO, István (org.). Brasil: formação do Estado e da Nação. São Paulo/ljui: Fapesp/Hucitec/Unijuí, 2003. p.195-218.
Por conseguinte, era aprovado um projeto em que a institucionalização de uma esfera de autonomia provincial pôde ser aceita mediante a concepção de fortalecimento do executivo local, cujo presidente era então reconhecido como peça fundamental de integração do Império sob a égide monárquica constitucional. Foi dessa forma que o arranjo institucional provincial que se consubstanciaria a partir de 1834, apoiava-se nesses dois principais pilares de autoridade: nos presidentes e nas Assembléias Legislativas locais.

Resta enfatizar que a onda de controle dos poderes políticos trazida pelos ventos das revoluções liberais - já bem mais amenos na década de vinte do século XIX - teve forte impacto na formação das bases jurídicas do Império do Brasil. A análise do caso específico da criação normativa dos cargos de presidentes confirma uma das facetas que o arranjo políticoinstitucional teria no novo Estado independente: a de que a construção dos canais de representação política, vinculados à expressão dos interesses dos "povos" e à composição das esferas do legislativo, foram sempre projetadas mediante um conseqüente incremento das funções ligadas à prática da administração, ou seja, ao executivo. E ainda que nas duas primeiras legislaturas, marcadas por uma tendência reformista colocada em prática por uma série de reformas liberais 83 , tenha havido uma ênfase na proposição de um controle local sobre a autoridade presidencial (conforme o texto aprovado, apenas entre os deputados em 1828, para os Conselhos terem ingerência sobre sua ação), a mesma não existiu no momento da reforma. Com o Ato Adicional e aprovação do regimento para os presidentes em 1834, a esfera de ingerência sobre a ação do presidente seria confinada sobretudo ao Imperador. Revela-se, portanto, a importância com que o executivo central foi concebido pelos nossos primeiros legisladores quando o assunto era a criação normativa de um regime monárquico que temeu, mais do que tudo, as ameaças à sua estabilidade política interna.
Recebido para publicação em julho de 2007

Aprovado em outubro de 2007 